$$
\text { 表 }-4 \text { 鯖 }
$$

油

\begin{tabular}{|c|c|c|c|c|c|c|c|c|c|c|}
\hline $\begin{array}{l}\text { 試料 } \\
\text { 番号 }\end{array}$ & 漁獲地 & $\begin{array}{c}\text { 漁獲月日 } \\
\text { (1951) }\end{array}$ & 比 $\left(\mathrm{d}_{4}^{20}\right)^{\text {重 }}$ & $\begin{array}{c}\text { 屈 折 率 } \\
\left(\mathrm{n}_{\mathrm{D}}^{20}\right)\end{array}$ & 酸 & 襝 化 価 & $\begin{array}{l}\text { 沃素価 } \\
\text { (Wijs法) }\end{array}$ & $\begin{array}{c}\text { 不鹼化物 } \\
(\%)\end{array}$ & 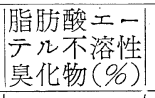 & 備 考 \\
\hline 1 & 釗 路. & 9. 上 & 0.9246 & 1.4794 & 3.5 & 188.9 & 166.1 & 1.45 & 58.11 & 体 \\
\hline 2 & 広 尾 & 8.21 & 0.9217 & 1.4780 & 3.2 & 190.4 & 157.9 & 0.41 & 44.30 & 内蔵, 頭 \\
\hline 3 & 広 尾 & 8.29 & 0.9216 & 1.4780 & 6.6 & 191.8 & 157.9 & 1.24 & 52.74 & 内蔵 \\
\hline 4 & 釧 路 & 8.5 & 0.9215 & 1.4782 & 26.8 & 187.0 & 156.2 & 3.02 & 50.46 & 体 \\
\hline 5 & 釗 路 & - & 0.9220 & 1.4766 & 7.7 & 187.6 & 155.2 & 1.53 & 45.40 & 体 \\
\hline 6 & 釧 路 & 9. 上 & 0.9208 & 1,4782 & 0.38 & 193.4 & 153.0 & 1.11 & 43.12 & 内藏 \\
\hline${ }^{+} 7$ & 釧 路 & - & 0.9199 & 1.4770 & 26.7 & 196.6 & 153.0 & 0.64 & 48.92 & - \\
\hline 8 & 広 尾 & 8.26 & 0.9212 & 1.4780 & 4.0 & 192.3 & 152.2 & 1.06 & 49.67 & - \\
\hline 9 & 釧 路 & - & 0.9210 & 1.4780 & 7.7 & 196.0 & 152.2 & 1.43 & 49.66 & - \\
\hline 10 & 釧 路 & 9. 上 & 0.9217 & 1.4781 & 0.31 & 189.1 & 152.0 & 1.31 & 46.91 & 内蔵 \\
\hline 11 & 釧 路 & 8. 中 & 0.9219 & 1.4772 & 24.8 & 191.5 & 151.1 & 1.32 & 40.49 & 内蔵, 頭 \\
\hline 12 & 小 樽 & 6. 上 & 0.9226 & 1.4783 & 9.3 & 193.7 & 148.9 & 1.30 & 48.67 & - \\
\hline 13 & 広 尾 & 8.26 & 0.9206 & 1.4780 & 0.64 & 193.7 & 148.6 & 0.47 & 49.14 & - \\
\hline 14 & 広 尾 & 8.27 & 0.9215 & 1.4780 & 7.7 & 190.9 & 148.4 & 0.88 & 49.56 & - \\
\hline 15 & 小 樽 & 6. 上 & 0.9210 & 1. 4780 & 1.0 & 191.7 & 143.9 & 1.17 & 49.71 & - \\
\hline 16 & 小 樽 & 7. 上 & 0.9178 & 1.4764 & 10.3 & 194.4 & 139.7 & 1.38 & 39.84 & - \\
\hline 最高 & & & 0.9246 & 1. 4794 & 26.8 & 196.6 & 166.1 & 3.02 & 58.11 & \\
\hline 最低 & & & 0.9178 & 1. 4764 & 0.31 & 187.0 & 139.7 & 0.41 & 39.84 & \\
\hline 平均 & & & 0.9213 & 1.4778 & 8.79 & 191.8 & 152.3 & 1.23 & 47.92 & \\
\hline
\end{tabular}

（備考）漁獲地はすべて北海道，備考欄は採油に用いた魚の部分を示したるのである。

、鹼化物 $2.45 \sim 6.94 \%$ (4.03\%), 脂肪酸エーテル不溶性 臭化物 64.71 79.27\% (73.93\%) である。また數種の 試料に就て試驗した結果, 混合脂肪酸中の飽和酸 $25 \sim 27$ $\%$, 油中の三飽和グリセライド 1 2\% 程度, $\mathrm{E}_{1 \mathrm{~cm}}^{1 \%} 328$ $: \mathrm{m} \mu 0.418 \sim 0.585$ である。

2. 鮮油 16 試料の特數範園 (括弧內は本詓值) を示 すと $\mathrm{d}_{4}^{20} 0.9178 \sim 0.9246(0.9213), \mathrm{n}_{\mathrm{D}}^{20} 1.4764 \sim 1.4794$ ( (1.4778), 酸價 $0.31 \sim 26.8(8.79)$, 图僉化價 $187.0 \sim 196.6$ i(191.8), 沃素價 139.7 166.1(152.3), 不鹼化物0.41〜 $3.02 \%$ (1.23\%), 脂肪酸エーテル不溶性臭化物 39.84〜 $58.11 \%(47.92 \%)$ である。また數種の試料と就て試驗 乙た結果, 混合脂肪酸中の飽和酸 $22 \sim 25 \%$, 油中の三飽 和グリセライド 1〜3\% 程度, $\mathrm{E}_{1 \mathrm{~cm}}^{1 \%} 328 \mathrm{~m} \mu \quad 0.144 \sim$
0.328 である。

（昭和 28 年 3 月 9 日受理）

\section{交献}

1）辻本满丸, 東工試報, 9,24（1915）；25, 第 4 號 61 (1930)

2) 辻本滿丸，木村包介，東工試報， 22 , 第 12 號， 73 (1927)

3) 北林邦次, 中村邦典, 首藤勝夫, 北海道水産試月 報，7，第 9 號 (1950)

4) 辻本满丸, 東工試報, 21, 第 6 號, 98 (1926)

5) E.André, H. Canal, Compt. rend., 183, 152(1926)

6) 辻本滿丸，東工試報，6，24（1911）

7) Grün-Halden, Anxlyse der Fette und Wachse, II, 370

8) T.P. Hilditch, C.H. Lea, J.Chem. Soc., 1927, 3106

\title{
含油量の少い柔魚肝臟並に柔魚油煮取粕 からのエーテル抽出油に就て
}

外山修芝・高井英子*・山田實**

The Ether Extraction Oils from the Cuttle-Fish Liver of Low Oil

Content and the Residue of Cuttle-Fish Oil Rendering.

Yoshiyuki Toyama, Hideko Takai, Minoru Yamada 
著者 ${ }^{1)}$ はさき柔魚油 (煮取油)の性狀に就て報告し たが，今回和歌山縣南方海上で漁獲された含油量の少い 柔魚肝臟を入手して實驗室に和いてエーテル抽出により 採油し, 油の性狀を試驗した結果, これらのエーテル抽出 油はさきに報告した煮取油にくらべてその性狀が著しく

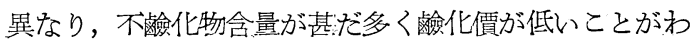
かつた。今回入手した柔魚肝臟は含油量が少く, 北海道 では8月以前に漁獲され一般に採油に用いられない柔魚 の肝臟飞匹敵するものである。このよう.と含油量の少い 肝臟の油煮取法によつて採油に用いられる含油量の多 い肝臟の油にくらべて一般にとの性狀が異なり，不畧化 物含量が多いということも考学られるが，採油方法の相 違によつて油の性狀が異なるということも考えられる。 師ら煮取法では肝臟中の不瞼化物成分が允分飞探取され ないで煮取粕中に殘留するが，エーテル抽出法によれば 不鹼化物成分子一樣に抽出され，從つて抽出油の不襝化 物含量は煮取油の不獣化物含量よりる一般に多いのでは ないかと考えられる。よつて著者は北海道で採製された 煮取柔魚油と共飞との煮取粕 (煮取廢液) を入手して煮 取粕からエーテル抽出によつて油を採取し, 煮取油と粕 からの抽出油との性狀を比較した。その結果, 粕からの 抽出油は例外なく煮取油よりも不瞼化物含量が多いこと を認めた。要するに今回試驗した含油量の少い柔魚肝臟 のエーテル抽出油の性狀がさきに報告した煮取柔魚油の 性狀と異なることは探油に供した柔魚の漁獲地や漁獲季 節の相違ばかりではなく，める程度採油方法の相違にも よるものと認められる。今回試驗したエーテル抽出油の 中でも不䩎化物含量 $48.30 \%$ の 8 のは例外的試料であ つて，かように不䌞化物含量が異常に多いととに對して 怡何等か他江未知原因が存在するすのと思われる。

惹取粕からのエーテル抽出油は煮取油よりる多量の不

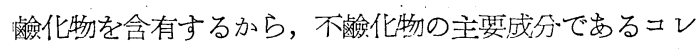
ステリンの採製原料としては煮取油よりも寧ろ煮取粕か らの抽出油の方が好適と認められる。

\section{1. 含油量の少柔魚肝臟のエーテル抽出油}

供試桑魚は名古屋市內の魚商から購入した。魚商はヤ リイカ (槍鳥賊) と稱していたが，事實はヤりイカで無 くスルメイカ（正確にはスルメイカ科屬するイカ）で 岕る。供試柔魚の漁獲地は和歌山縣南方海上で漁蒦日は 購入した日の數日前と認められる。供試柔魚は購入した 當日に肝藏を分離し,これを細斷して徐々に加熱し 30 分 〜 1 時間を要して $95^{\circ} \mathrm{C}$ になつたとき加熱を止め，冷却 して得た泥狀物に約 2 倍量のエーテルを加えてよく振り

*名古屋大學工學部應用化學敎室 (名古屋市千種區不老町) Department of Applid Chemistry, Faculty of Engineering, Nagoya University
静置して分離したエーテル液を拢き取り，粕は更と多數 回エーテルで抽出した。抽出は完全には行わなかつたが 最終回の抽出によつて得たエーテル液は微黃色で肚臟中 の油は大部分抽出されたものと認められた。エーテル液 は全部合一して脫水芒硝で脫水した後エーテルを溜去し 抽出油を收得した。このものはホスファチドを含有する から，これに 10 倍量のアセトンを加えてアセトン不溶 のホスファチドを除き，アセトン可溶の油を收得した。 かくして得た油は著大の酸價を示したから，遊離酸を除 くため油をエーテル溶液とし苛性カり液を加兄て遊離酸 をカリ石䖒としてエーテル溶液から分離し，エーテル溶 液から低酸價の油を收得した。以上の實驗結果を示すと 表-1 の通りである。表-1 の試料番號 3 文び 4 は同時に 購入乙た柔魚で, 形體の大小迄つて 2 群に分け大形の ものを試料番號 3 とし小形のものを試料番號4 とした。

表-1 の油 (苛性カリ處理後のアセトン可溶油) は試料 番號 2 以外は常溫飞和いて結晶狀固體を交主體として 流動しない。殊飞試料番號 4 は硬い固體である。試料番 號 2 は流動するが底部に結晶狀固體を析出した。これら の油の性狀（表一2）はさきに報告した煮取油の性狀と異 なり不簽化物含量が多く，特に試料番號 4 は不僉化物含 量が異常に多い。また脂肪酸エーテル不溶性臭化物の收 量も甚だ多く, 試料番號 2 及び 6 亿和いては $80 \%$ 以上 であることが注目される。

試料番號 $2 ， 4 ， 5$ の不瞼化物に就てジギトニン法によ 表 -2

\begin{tabular}{|c|c|c|c|c|c|}
\hline $\begin{array}{l}\text { 弪料 } \\
\text { 番號 }\end{array}$ & $\begin{array}{c}\text { 比 }\left(\mathrm{d}_{8}^{4}\right) \\
\text { 重 }\end{array}$ & 鹼化價 & $\mid$\begin{tabular}{c|} 
沃素價 \\
(Wijs 法)
\end{tabular} & \begin{tabular}{|l|} 
不噞化物 \\
$(\%$
\end{tabular} & $\begin{array}{l}\text { 脂肪酸エー } \\
\text { テル溶性 } \\
\text { 臭化物 }(\%)\end{array}$ \\
\hline 1 & 0.8969 & 155.4 & 155.5 & 18.59 & 75.57 \\
\hline 2 & 0.8842 & 172.8 & 206.4 & 9.64 & 85.67 \\
\hline 3 & 0.8826 & 156.5 & 196.5 & 16.04 & 78.04 \\
\hline 4 & 0.8969 & 130.3 & 185.2 & 48.30 & 72.74 \\
\hline 5 & 0.8852 & 158.8 & 173.3 & 15.34 & - \\
\hline 6 & 0.8847 & 164.1 & 194.3 & 14.70 & 81.73 \\
\hline
\end{tabular}

りステリンを定量した結果は，それぞれ $66.32 \%, 82.71$ $\% ， 72.29 \%$ である。また試料番號 4 の油に就て遊離ス テリンを定量した結果は $24.31 \%$ であから，不襝化物 の主成分はステリンであり且つステリンの一部は遊離ス テリンとして油中に含まれているととがわかる。各試料 番號の不䎥化物を集め, これをエタノールから3 回再結 晶したものは融點 $145^{\circ} \mathrm{C}$ でニレステリンと認められた。

\section{2. 柔魚油煮取粕からのエーテル抽出油}

**北海道大學水産學部 (函舘市港町)

Faculty of Fisheries, Hokkaido University 
柔魚肝臟の惹取油と，その惹取粕からのエーテル抽出 油とを比較するため下記 5 組の試料を製取した。本實驗 飞使われた柔魚は 1952 年 10 月〜 11月飞北海道函館附 近惠山沖で漁蒦されたものである。

A. 柔魚肝臟 (队獩) を自己消化したもの約 $1.2 \mathrm{~kg}$ を 入手し, これて水約 $3 l$ を加えて $90^{\circ} \mathrm{C}$ 附近飞加熱し, 次飞靜置して分離した油層と下層廢液とを分けた。油層

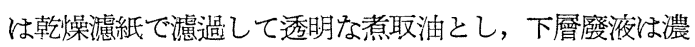
縮して約 $500 \mathrm{cc}$ とし，その一部をとつてェーテルで抽
出しエーテル抽出液から抽出油を收得し，これを更とア セトンで處理してアセトン不溶のホスファチドを除きア セトン可溶油を收得した。

B. 鰊釜で採製した煮取柔魚油と，その際釜の底部に 沈澱した殘㵏を入手し，残漳を蒸發乾涸して黑褐色の粒 狀物としエーテルで抽出した。粒狀物から $250 \mathrm{~g}$ エーテ ル抽出油 $56 \mathrm{~g}$ を收得し, これを更とアセトンで處理して アセトン可溶油 $50 \mathrm{~g}$ を收得した。

C. 前記 B と同樣として得た煮取油と煮取殘漳を入手

表 -1

\begin{tabular}{|c|c|c|c|c|c|c|c|c|c|c|}
\hline \multirow{2}{*}{$\begin{array}{l}\text { 詿料 } \\
\text { 番號 }\end{array}$} & \multirow{2}{*}{$\mid \begin{array}{l}\left|\begin{array}{l}\text { 購入月日 } \\
(1952 \text { 年 })\end{array}\right| \\
\end{array}$} & \multirow{2}{*}{ 個 數 } & \multirow{2}{*}{$\begin{array}{c}\text { 全重 量 } \\
\text { (g) }\end{array}$} & \multicolumn{2}{|l|}{ 肝 } & \multicolumn{2}{|c|}{ エーテル抽出油 } & \multicolumn{3}{|c|}{ アセトン可溶油 } \\
\hline & & & & 重量（g） & $\begin{array}{l}\text { 全重量に } \\
\text { 對する\% }\end{array}$ & 收量 (g) & $\begin{array}{l}\text { 肝獩に對 } \\
\text { する }\end{array}$ & 收量 (g) & 價 & $\begin{array}{l}\text { 坷性カリ處 } \\
\text { 理後の酸價 }\end{array}$ \\
\hline 1 & 1.9 & 31 & 5625 & 612 & 10.9 & 46 & 7.5 & - & 21.9 & 0.96 \\
\hline 2 & 1.10 & 27 & 5625 & 495 & 8.8 & 83 & 16.8 & 77 & 15.4 & 0.68 \\
\hline 3 & 2.14 & 27 & 5625 & 423 & 7.5 & 60 & 14.2 & 57 & 23.1 & 0.91 \\
\hline 4 & 2.14 & 45 & 8152 & 535 & 6.6 & 52 & 9.7 & 40 & 29.8 & 1.13' \\
\hline 5 & 2.29 & 40 & 8426 & 1207 & 14.3 & 120 & 9.9 & 115 & 28.6 & 0.57 \\
\hline 6 & 3.12 & 27 & 5692 & 810 & 14.2 & 109 & 13.5 & - & 23.9 & 0.85 \\
\hline
\end{tabular}

表 -3

\begin{tabular}{|c|c|c|c|c|c|c|c|c|}
\hline & & $\begin{array}{l}\text { 比 重 } \\
\left(\mathrm{d}_{4}^{20}\right)\end{array}$ & $\begin{array}{c}\text { 屈折率 } \\
\left(\mathrm{n}_{\mathrm{D}}^{20}\right)\end{array}$ & 酸＼cjkstart價 & 醶化價 & 沃素價 & \begin{tabular}{|c} 
不畧化物 \\
$(\%)$
\end{tabular} & 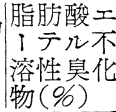 \\
\hline & A & 0.9209 & 1. 4812 & 29.0 & 179.2 & 185.5 & 4.48 & 73.20 \\
\hline 煮 & B & 0.9244 & 1.4830 & 8.8 & 179.2 & 187.4 & 3.47 & 70.05 \\
\hline 取 & $\mathrm{C}$ & 0.9245 & 1.4829 & 11.1 & 179.6 & 182.1 & 3.57 & 69.13 \\
\hline 油 & $\mathrm{D}$ & 0.9245 & 1.4829 & 8.5 & 180.1 & 181.3 & 3.30 & 71.58 \\
\hline & $\mathrm{E}$ & Q. 9240 & 1.4829 & 9.0 & 180.3 & 182.6 & 3.46 & 74.85 \\
\hline & A & 0.9276 & 1.4811 & 47.9 & 171.4 & 182.9 & 10.59 & 77.06 \\
\hline 取出 & B & 0.9296 & 1.4850 & 22.9 & 171.3 & 176.8 & 9.28 & 73.29 \\
\hline 粕油 & $\mathrm{C}$ & 0.9362 & 1.4839 & 33.4 & 181.0 & 170.3 & 9.15 & 66.61 \\
\hline 5 & $\mathrm{D}$ & 0.9338 & 1.4830 & 47.2 & 185.5 & 167.2 & 8.84 & 66.40 \\
\hline & $\mathrm{E}$ & 0.9224 & $1.482 \mathrm{C}$ & 111.9 & 176.7 & 182.3 & 10.02 & 66.88 \\
\hline
\end{tabular}

し, 煮取殘滓を蒸墢濃縮して泥狀物としエーテル抽出に よつて泥狀物 $219 \mathrm{~g}$ から抽出油 $41 \mathrm{~g}$ を得, これをアせ トンで處理してアセトン可溶油 $36 \mathrm{~g}$ を得た。

D. 前記 $\mathrm{B}$ と同樣として得た煮取油と煮取残㳯を入手 し，煮取殘㳯からの泳狀物 $200 \mathrm{~g}$ をエテルで抽出して 抽出油 $34 \mathrm{~g}$ を得，これをアセトンで處理してアセトン 可溶油 $30 \mathrm{~g}$ を得た。

E. 鰊釜で惹取油を採取し，煮取廢液は遠心分離機に かけて水分を分け泥狀物を收得した。この泥狀物 $345 \mathrm{~g}$ からエーテル抽出により抽出油 $30 \mathrm{~g}$ を得，これをアせ トンで處理してアセトン可溶油 $28 \mathrm{~g}$ を得た。

以上 5 組の試料飞就て惹取油と惹取粕からのエーテル 抽出油(アセトン可溶油)との性狀を比較しだ結果ば表一

\section{3 の通りである。}

表-3 とよると煮取粕からの抽出油ば,

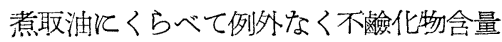
が多い。惹取粕からの抽出油の不襝化物 を10〜15 倍量のエタノールから1回再 結晶したものは融點 $145^{\circ} \mathrm{C}$ をしコレス. テリンと認められた。表-2 の含油量の少 认肝臟の抽出油中飞は脂肪酸エーテル不 溶性臭化物の收量が甚だ多いものがあつ たが,表-3 とよると惹取粕からの抽出油 は脂肪酸エーテル不溶性臭化物の收量が. 寧ろ少いるのがある。これは今回の實驗 そ赫いて惹取粕の處理操作中飞高度不飽: 和酸成分が多少酸化を受けたためでない かとも思われる。

\section{3. 總 括}

1. 含油量の少い柔魚肝臟のエーテル抽出油（アセト ン可溶油）は不翮化物含量が甚だ多く；殊飞との一試料 は不䖒化物含量が $48 \%$ で異常飞多い。また脂肪酸工一 テル不溶性臭化物の收量も概して多く, 80\%を越光るも のがある。

2. 同じ柔魚肝臟 (內贜) の惹取油と煮取粕からの工. ーテル抽出油（アセトン可溶油）とを比較すると後者は: 不鐱化物含量が多い。（昭和 28 年 4 月 13 日受理）

\section{交 献}

1）山田實，高井英子，水田政輝，然山修之，本誌。 2. 149 (1953) 